\title{
The Research of China's Low Carbon Economy Situation and Countermeasures
}

\author{
Zhang Tingfa \\ Jinan, China \\ School of Economics and Management \\ Qilu Normal University \\ e-mail: ztfsdu2011@163.com
}

\author{
Sun Peng \\ School of Economics and Management \\ Qilu Normal University \\ Jinan, China \\ e-mail: alexsp@163.com
}

\begin{abstract}
Low carbon economy is based on low energy consumption, low emissions and low pollution. China has currently the advantage about the low carbon economy, but there are still many adverse factors, such as traditional pattern of economic development, which leads to the high energy consumption, high emission and low technical level, a difficult task of energy conservation and emissions reduction, so China needs to adopt some measures such as adjusting industrial structure, speeding up scientific and technological innovation, strengthening international cooperation and exchange in low-carbon technology, and formulate the corresponding countermeasures.
\end{abstract}

Keywords-low carbon economy; energy structure; industrial structure; energy conservation and emissions reduction; ecological civilization

\section{INTRODUCTION}

Under the background of global warming, low-carbon economy is paid attention to by more and more nation. They believe that developing low carbon economy can improve the utilization efficiency of energy in existence and reduce greenhouse gas emissions, which can reduce the negative impact of economic growth on the ecological environment and global climate, then in order to realize the goal of ecological civilization, China must can achieve economic and social sustainable development by adopting some kinds of countermeasures.

\section{THE INEVITABILITY OF CHINA'S LOW-CARBON ECONOMY DEVELOPMENT}

\section{A. Low carbon economy to meet the needs of the future}

The biggest temperature increases in the 20th century are the two periods between 1910-1945 and 1976-1945, especially during the 30 years since 1980, global warming is more obvious. The average temperature in those days except for few years is higher than the average temperature for a long time.

The concentration of carbon dioxide in the atmosphere increased by 2.3 PPM than one in 2009, the growth is higher than 2.0 parts per million of the average annual growth in recent 10 years. Due to the extensive use of fossil fuels and deforestation and change of land use, since the start of the process of industrialization, concentration of carbon dioxide in the atmosphere has increased $39 \%$. High energy consumption, high emission and high pollution of fossil fuels can no longer support the sustainable development of human beings. At the same time, the scarcity of fossil fuels, irrefragable makes it inevitable to increase energy efficiency and adjust the energy.

\section{B. Low carbon economy leads to ecological civilization}

Low carbon economy is the economic model on the basis of low energy consumption, low emissions and low pollution, which is another big progress of the human society after agricultural civilization and industrial civilization. The essence of low carbon economy whose core is the technology innovation, system innovation and the transformation of development view is to improve the energy efficiency and innovate the clean energy structure. So, developing low-carbon economy is a global revolution concerned with production mode, life style, values and national rights, then development of low carbon economy is inseparable with the construction of ecological civilization.

1) Low carbon economy to adapt to the natural system requirements

Global warming and a series of ecological problems are the important content of the ecological crisis faced by the human society. Therefore, to put forward low carbon economy is a product of natural system requirements, it is helpful to resolve a series of climate, water resources, energy and ecological system for the formation of a good environment.

2)Low carbon economy in accordance with production relations change

3)Low carbon economy is the development model of innovation

4)Low carbon economy is an important part of ecological civilization construction

So, it is the inevitable choice to develop low-carbon economy, transform the mode of energy resources utilization and develop alternative energy and renewable energy, improve the efficiency of energy utilization. Effective promotion of low-carbon economy is an effective way to construct ecological civilization. 


\section{CHINA'S LOW CARBON ECONOMY DEVELOPMENT PRESENT SITUATION}

\section{A. Unreasonable energy consumption and energy structure}

China's per capita energy resources ownership in the world is low, but energy consumption is gradually increasing. China's energy consumption growth in 2010 was $11.9 \%$ that account for $20.3 \%$ of global energy consumption, thus China becomes the world's largest energy consumer than the United States, such as Fig .1. (The curve of red color presents China, The curve of yellow color presents America ).

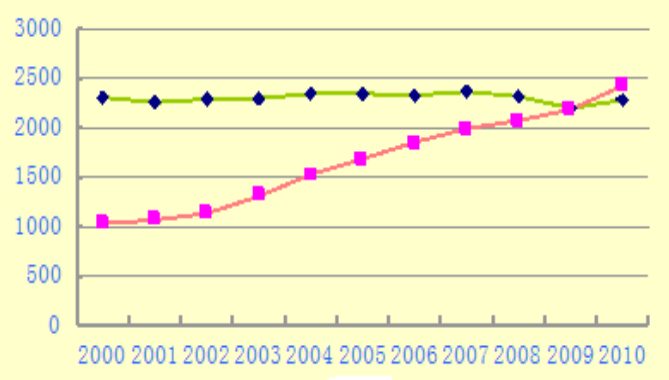

Figure 1. Primary Energy Consumption.

China's per capita energy resources ownership in the world is low, but energy consumption is gradually increasing. China's energy consumption growth in 2010 was $11.9 \%$ that account for $20.3 \%$ of global energy consumption, thus China becomes the world's largest energy consumer than the United States.

In China's primary energy consumption structure, coal still occupy large proportion which is $70.45 \%$, but clean energy is only a small proportion, such as water and electricity is $6.72 \%$, nuclear power is $0.69 \%$, renewable energy is $0.60 \%$, at the same time, more clean natural gas, nuclear power, geothermal energy has occupied a very small proportion. The high carbon energy structure given priority to with coal is not only a great threat to the environment, which does not meet the requirements of the development of low-carbon economy, but also it restricts the transformation of china economy development mode.

Typical carbon energy economy mode make China's carbon dioxide emissions intensity relatively high. According to the statistical results, China's carbon dioxide emissions caused by primary energy consumption whose average annual growth rate achieves $5.84 \%$ are 786.78 million tons of carbon in 1995 but 1.46919 billion tons of carbon in 2006, meanwhile the per capita carbon dioxide annual emissions increase from 0.62 tons of carbon to 1.12 tons of carbon.

China's carbon dioxide emissions has surpassed the United States in 2007 to become the first in the world, in which industrial sector co2 emissions accounted for more than $84 \%$ of China's carbon emissions. Therefore, energy conservation and emissions reduction in China is very serious. If China continues to use traditional techniques and develop high carbon industry, when the future need commitment to greenhouse gas emissions or quantitative limits obligation, china is likely to be "locked" by the high carbon industry.
Of course, we can see from table 1 that China's efforts to reduce energy consumption per unit GDP achieved good results during the period of "11th five-year plan".

TABLE I CHINA'S ENERGY CONSUMPTION CHANGE PER UNIT GDP

\begin{tabular}{|c|c|c|c|c|c|}
\hline year & 2006 & 2007 & 2008 & 2009 & 2010 \\
\hline change & $-2.74 \%$ & $-5.04 \%$ & $-5.20 \%$ & $-3.61 \%$ & $-4.15 \%$ \\
& & & & & \\
\hline
\end{tabular}

To sum up, facing the increasingly serious energy and environmental problems, China has already realized the importance of low carbon economy for sustainable development of human. Especially under the background of the low carbon economy paid attention to by the countries of the world gradually, China must keep up with the pace of The Times. Through the policy documents and measures to develop low carbon economy, China can achieve social and economic transformation and maintain continuous international competitiveness and development momentum.

\section{B. Industry structure and industry energy consumption}

The ratio between three industries is a strong evidence of low-carbon economy development. Now, the second industry still dominates in China and accounts for $46.8 \%$ of the total amount, although the data between the tertiary industry and the second industry is similar, but the industry energy consumption exists obvious difference. The second industry, that is the industry, energy consumption has accounted for more than seventy percent of the total energy consumption, and most of them are production mode of high consumption, high pollution.I

\section{High energy consumption and serious environmental pollution}

Extensive mode of economic growth in our country are dominant at present and the whole production process still exists the phenomenon of high consumption, high pollution, which can be seen from electric power consumption elasticity coefficient and energy consumption elasticity coefficient. In recent years, China's electricity consumption elasticity coefficient is relatively large, even greater than 1, this kind of phenomenon illustrates very intuitively that China's economic growth largely rely on electricity consumption to maintain.

Low carbon economy development has something to do with environmental protection, but at present environmental pollution is very serious with China's economic development simultaneously, especially environmental pollution conditions in China have been exacerbated by some of the second industry of high consumption, high pollution, high emissions to adverse to the development of low-carbon economy.

\section{Imperfect laws and regulations of low carbon economy development}

Although as early as 1989 China established a national "environmental protection law of the People's Republic of China" to ensure China's environmental protection and promote the development of low-carbon economy, since then, China has enacted "the law on the prevention and 
control of environmental pollution by solid waste", "the energy conservation law," "circular economy promotion law "and other relevant laws and regulations, but there are some obvious deficiencies in some more detailed provisions, therefore China's laws and regulations need further be improved.

\section{THE EXISTING PROBLEMS IN THE DEVELOPMENT OF LOW CARBON ECONOMY IN CHINA}

\section{A. Long-term mechanism of energy conservation and emissions reduction need to be established}

At present China's pressure and driving force to promote the development of green low carbon mainly comes from the governments at all levels, from various control means, executive order color is thick, thus the problem of insufficient endogenous dynamics in driving energy conservation and emissions reduction is more outstanding. For example, the central government decomposes the energy saving target to all provinces. The provinces decompose the target to the prefecture level cities and so on. The government at a higher level for the governments at lower levels uses "first-class catch level 1 , level 1 assessment level 1" management style.

\section{B. Not strong market signals guide}

The price and the tax system of China's resources and environment do not play a role of "light" and "baton" in energy conservation and emissions reduction, which is the main cause that many enterprises have not high enthusiasm in energy conservation and emissions reduction. For a long time, China resources prices only contain mining and transportation costs and do not reflect environmental damage in the mining process, pollutants of processing the process and environmental impact in the process of greenhouse gases emission and use. In fact, environmental governance costs are often ignored, or environmental governance is given the burden to the local government. The mechanism of resource products price and tax is difficult to draw the responsibility of the enterprise, government and consumers, which is not conducive to definition and share of energy conservation and emissions reduction, eventually lead to the public welfare damage, such as air, river, water. China has not yet issued carbon tax policy.

\section{Laws and regulations standard and execution needs to be improved}

Laws and regulations to protecting green low carbon development are still not enough perfect. China lacks of an overall law responding to climate change. Some related laws in the energy field, such as "coal law" and "electric power law" and so on, are issued both before and after the 1990s, and already cannot satisfy the requirements for turning green low carbon development. In addition, the law enforcement and effect carried out are unsatisfactory.

\section{Low carbon development market and imperfect service system}

At present, service system related to China green low carbon economy is relatively lacking. These services organizations include financial and technical support, information consultation, the third party audit and certification, the carbon market, etc. Foe example, financial services of green low carbon development is in bud, though green finance has preliminary interest to financial circles, financial credit how to merge with energy conservation and emissions reduction, low carbon development, how to innovate and spawned a conducive business model and credit business to energy conservation and emissions reduction, still need to grope for a period of time.

\section{E. Emissions rights trading system still need further exploration}

From the experience of developed countries, the carbon emissions right trading is one of the effective measures to improve the carbon emissions funds service efficiency of the whole society under the condition of market economy. Since 2005, European launch the carbon emissions trading, and for nearly 10 years of practice, has now entered into the third stage. China's carbon emissions trading just try water stage, and only carry out the carbon emissions trading in seven provinces and municipalities such as Beijing City, Tianjin City, Shanghai City, Chongqing City, Hubei province, Guangdong provinceand Shenzhen City.

\section{SUGGESTIONS TO PROMOTE THE DEVELOPMENT OF LOW CARBON ECONOMY IN OUR COUNTRY}

\section{A. To further strengthen environmental pollution control}

Environmental pollution is a major factor to constraint the development of low carbon economy in China, and the unreasonable economic structure and development make the environment pollution condition further worsen. This is the first thing we must carry on the management of the main reasons, one of the most important measure is to increase investment in environmental protection funds, facts prove that our country is also gradually to increase the investment proportion, but the degree is not enough, we need to further increase investment, strengthen environmental pollution control ability. On the other hand, we should also strive to improve their own scientific and technological level of pollution control, adopts the new type of high-tech to enhance their own level of pollution control.

\section{B. Adjusting industry structure}

At present, the energy consumption of second industry in China is very big, which causes the very serious environmental pollution, so it is imperative to adjust industrial structure. First of all, to strengthen regional economic cooperation aims at adjusting the industrial structure. For example, under the background of ChinaAsean free trade area, China should develop the small light industry in the southwest of China bordering on Asean so as to accelerate the industrialization; Secondly, vigorously developing modern service industry and striving to create service brand will change and improve China's industrial structure and development level; Finally, China need to eliminate outdated technology and replace small scale production by means of mass production by improving the industry competition mechanism. 


\section{Optimizing energy structure, improving energy efficiency}

At present, the energy consumption is given priority to with coal so that proportion of energy consumption in China has reached more than $70 \%$ to form irrational energy structure in China, so China need vigorously develop and utilize new energy sources, such as biomass energy, ocean energy, light energy to optimize energy structure and come true the economic sustainable development. In addition, China need start two aspects of management and technology to improve energy utilization. In management, China need formulate industry standards, objectives and policies and measures of energy saving and consumption reducing to supervise industry energy consumption situation, etc., encourage enterprises to improve energy efficiency; In terms of technology, trough the high and new technical transformation and upgrading traditional industries, China must develop and promote the new technology, improve the utilization rate of raw coal and crude oil, and strengthen the coal washing and processing, coal desulfurization.

\section{Further strengthen the government's key role in energy conservation and emissions reduction}

The government should play a role in tax and make the tax policy to promote recycling economy development and play a positive role in energy conservation and emissions reduction, etc. Through encouragement to businesses and individuals, China should increase capital investment and gradually formed the government guide the reduction situation of the whole society to participate. In addition, the government need formulate relevant laws and regulations, and strengthen energy conservation and emissions reduction.

\section{E. Development of low carbon finance}

Another key focus of low carbon economy development is low carbon finance.

At present, China has made certain achievements in providing low carbon finance funds and establishing carbon emissions trading mechanism, such as table 2.

Finance can play an important role in the process of development of low carbon economy, including provision of construction funds required of low carbon economy development and establishment of an effective carbon emissions trading market and forming accurate price signals, at the same time, promotion of various kinds of financial derivatives related with the reduction, etc. At present,

China has made certain achievements in providing low carbon finance funds and establishing carbon emissions trading mechanism.

TABLE II PROJECTS OF CHINA'S COMMERCIAL B ANKS TO SUPPORT OF ENERGY-SAVING EMISSION REDUCTION

\begin{tabular}{|l|l|}
\hline central bank & $\begin{array}{l}\text { In the aspect of energy conservation and emissions reduction, credit balance has exceeded } \\
180 \text { billion RMB , double-digit } \\
\text { annual growth rate in 2010. }\end{array}$ \\
\hline agricultural bank & $\begin{array}{l}\text { In 2009, veto } 83 \text { considering environmental protection projects, support energy conservation } \\
\text { and emission reduction } 1803 \text { projects }\end{array}$ \\
\hline $\begin{array}{l}\text { Industrial and Commercial } \\
\text { Bank }\end{array}$ & By 2009, nearly 400 billion RMB loans in energy conservation and environmental protection \\
\hline construction bank & 152.5 billion RMB in Renewable energy loans of by 2008 \\
\hline $\begin{array}{l}\text { Bank of } \\
\text { Communications }\end{array}$ & $\begin{array}{l}\text { In 2009, energy conservation and environmental protection project loans } 578.1 .5 \text { billion } \\
\text { RMB }\end{array}$ \\
\hline Industrial Bank & $\begin{array}{l}\text { In October 2008, formal public commitment to adopt the equator principles, and to become } \\
\text { China's first bank of the equator }\end{array}$ \\
\hline China Development Bank & In 2009, 139 billion RMB lending for energy conservation and environmental protection, \\
\hline
\end{tabular}

\section{F. Development of ecological environmental protection industry}

In agriculture, China must take the path of advanced agriculture and environmental protection, with the help of vigorously promoting the efficient ecological agriculture, strengthening the deep processing of agricultural products, improving the added value of agricultural products. In addition, china must increase the intensity of characteristic resources development to transform the resources advantage into industrial advantage as soon as possible.

In the ecological industry, China must adhere to the road of new industrialization, develop circular economy, accelerate the construction of ecological industrial park and no pollution, low energy production technology.

In terms of ecological tourism, China must vigorously develop green tourism on the basis of low energy consumption, low pollution and change the traditional extensive tourism mode, improve the sci-tech contents in tourism industry, reduce dependence on resources environment, and develop low-carbon tourism of resource saving and environmentally friendly..

\section{CONCLUSIONS}

Currently, the development situation of low carbon economy in China is not optimistic, and also there are many problems in the process of development restricting the development of low carbon economy in China. How to take effective measures to solve these problems and provide necessary conditions for the development of low carbon economy is still the first problem that we urgently need to solve.

\section{REFERENCES}

[1] K Parikh. Sustainable development and low carbon growth strategy for India[J]. Energy, 2012, 40(1):31-38.

[2] Furman, J.L., Porter, M.E., Stern, S. The determinants of national innovative capacity [J]. Research Policy, 2002,31(6):899-933.

[3] . UK Rout. Prospects of India's energy and emissions for a long time frame[J]. Energy Policy, 2011,39(9):5647-5663 
[4] P Balachandra, D Ravindranath, NH Ravindranath. Energy efficiency in India: Assessing the policy regimes and their impacts[J]. Energy Policy, 2010,38(11):6248-6438.

[5] Hu, X., Murgovski, N., Johannesson, L., Egardt, B. Energy efficiency analysis of a series plug-in hybrid electric bus with different energy management strate gies and battery sizes[J]. Energy, 2013, 111(11):1001-1009.

[6] Yang, Z., Kang, L., Niu, Q., et al. A self-learning TLBO based dynamic eco nomic/environmental dispatch considering multiple plug in electric vehicle. loads[J]. Cle. Energ, 2014, 2 (4), 298-307.

[7] Ocran, T., Cao, J., Cao, B., et al. Artificial Neural Network Maximum Power Point Tracker for Solar Electric Vehicle. Tsinghua Sci. Tech. 2005,10 (2), 204-208.

[8] Ding, Y., Yang, H. Promoting energy-saving and environmentally friendlygeneration dispatching model in China: phase development and case studies [J]. 2013, Energy Policy 57(6):109-118.
[9] Gao, C., Li, Y., Evolution of China's power dispatch principle and the newenergy saving power dispatch policy[J]. Energy Policy, 2010, 38(11): 7346-7357.Electronic Publication: Digital Object Identifiers (DOIs):

[10] Ji, S., Cherry, C.R.,J., Bechle, M., Wu, Y., Marshall, J.D. Electric vehicles in China:emissions and health impacts[J]. Environ. Sci Technol, 2012, 46 (4), 2018-2024.

[11] Stern N. The Economics of Climate Change[M]. London: Cambridge University Press, 2006.

[12] IPCC. Climate Change 2007: migitation. Contribution of Working Group III . To the Fourth Assessment Report of the Intergovernmental Panel on Climate Change[R]. London: Cambridge University Press.,2007. 